\title{
Juvenile height growth rate of seven major tree species in a tropical rain forest of West Sumatra
}

\author{
Erizal MuKHTAR ${ }^{1}$ and Fumito KoIKE ${ }^{2}$ \\ ${ }^{1}$ Department of Biology, Faculty of Mathematics and Natural Sciences, Andalas University, Padang 25163, West Sumatra, Indonesia \\ ${ }^{2}$ Graduate School of Environment and Natural Sciences, Yokohama National University, 79-7 Tokiwadai, Hodogaya-ku, Yokohama 240-8501, \\ Japan
}

\begin{abstract}
Performances of juveniles are a key process for the existence of species in the community. Effect of topography, crowding effect and forest regeneration cycle, and conspecific plants in the context of Janzen-Connell hypothesis on height growth rate of seven major tree species were evaluated based on measurement of juveniles for nine-year period in a 1-ha plot of a tropical rain forest in West Sumatra, Indonesia. Height growth rate was significantly smaller in Calophyllum soulattri than other six species, and the latter species had approximately equivalent height growth rate. Growth rate was positively correlated with initial height in five species, but was negatively correlated in Calophyllum soulattri. Negative effect of conspecific juvenile density was detected by regression analysis only in Calophyllum soulattri. Topography was significant in two species (Hopea dryobalanoides and Mastixia trichotoma). Negative effects of total basal area including all species was found in one species (Swintonia schwenkii). Negative effects by conspecific plants was not dominant at least for height growth rate. Calophyllum soulattri was the only exception showing different behavior from the other species studied.
\end{abstract}

Key Words: Forest regeneration cycle, height growth rate, Janzen-Connell hypothesis, topography, tropical forest

\section{INTRODUCTION}

Regeneration is a key process for the existence of species in the community. Janzen-Connell hypothesis suggests better performance of juveniles at the distant places from the mother tree, and explains coexistence of tree species. Many attentions have been paid for seed dispersal and related processes (Nathan and Muller-Landau, 2000; Wilson and Traveset, 2001). Survivorship has been often studied in the context of Janzen-Connell hypothesis (i.e, Beckage and Clark, 2003; Nathan and Casagrandi, 2004; Beckage et al. 2005) but information on growth process was rare (i.e. Uriarte et al. 2004; Massey et al. 2006). Although various studies of tropical forests have reported on growth rates of juvenile trees (Rijker et al. 2000; Lusk and Pozo, 2002; Bloor and Grubb, 2003; Neptali, 2003; Pearson et al. 2003; King et al. 2005), they did not evaluated the effect of mother tree and conspecific neighbors.

Topography affects distribution of tree species. To explain the presence of a particular species in particular site (e.g. ridge or valley), effect of topography on growth of saplings needs to be considered. Forest regeneration cycle and crowding effect by trees and juveniles of all species is also important factor determining growth. We aimed to clarify juvenile height growth characteristics of seven major tree species in a tropical rain forest of West Sumatra, and evaluated importance of these factors in the context of Janzen-Connell hypothesis and response to topography.

\section{MATERIALS AND METHODS}

This study was carried out at a 1-ha permanent plot, named Pinang-pinang plot (590-620 $\mathrm{m}$ above sea level) in a foothill forest of Mt. Gadut (Lat. $0^{\circ} 55^{\prime}$ S, Long. $100^{\circ} 30^{\prime}$ E), $17 \mathrm{~km}$ east from Padang, West Sumatra, Indonesia. The long term study of tropical forests in this region started since 1980 (Kohyama et al. 1989; Yoneda et al. 1990, 1994, 2006; Suzuki and Kohyama, 1991; Mukhtar et al. 1992; 1998; Koike and Syahbuddin, 1993; Kohyama et al. 1994). The Pinang-pinang plot was set up in 1981 consisted of 115 subplots of approximately equivalent area. Position of all trees (DBH $>9 \mathrm{~cm}$ ) was mapped in 1981, and diameter measurement data in 1989 were used 
for our analysis. Details of stand descriptions could be referred to the previous papers (Kohyama et al. 1989; Yoneda et al. 1990; Mukhtar et al. 1992; 1998).

We chose seven species which are common and dominant in Ulu Gadut forest floor. The species were Swintonia schwenkii, Calophyllum soulattri, Hopea dryobalanoides, Cleistanthus glandulosus, Mastixia trichotoma, Grewia florida and Gonystylus forbesii. The detailed species characteristics of seven tree species in forest stand were mentioned in our previous paper (Mukhtar and Koike, 2007). The saplings (0-100 cm in height) and small juvenile trees (101-1000 cm in height) of the seven species were marked in September 1989, and re-examined in September 1998. Positions and plant height were measured in these surveys.

Annual height growth rate of each juvenile (height $<10 \mathrm{~m}$ ) was calculated for the duration from September 1989 to September 1998 using the following equation:

Annual height growth rate $=\left(H_{2}-H_{1}\right) /\left(t_{2}-t_{1}\right)$ where $H_{1}$ and $H_{2}$ are juvenile heights $(\mathrm{cm})$ at the first and second measurement, respectively, and $t_{2}$ and $t_{1}$ are calendar years of the measurements. Since correlation between growth rate and size was weak, an equation to estimate growth rate assuming exponential growth curve (Hunt 1982) was not applied in this study. Dead plants during the study period was not considered. Since the frequency distribution of height growth rate showed strong skewness, transformation by quadratic root was applied for calculation of average value and statistical test of height growth rate.

For analysis of size dependency in growth rate, Pearson's correlation coefficients were calculated between initial heights and growth rates for each species. Among-species differences in growth rate were analyzed for smaller and larger juveniles independently because we found significant size dependency in most species. We classified the juveniles into two groups: saplings (initial height $\leq 1 \mathrm{~m}$ ) and small trees (initial height $>1 \mathrm{~m}$ ). Differences in height growth rate among studied species were tested by multiple t-test with Bonferroni correction (SPSS 12.0J, SPSS Japan Inc., Tokyo).

In order to know the factors determining height growth rate, the following linear regression was conducted. For removal of initial height effect, we did not used growth rate but used the residuals of species specific linear regression models between growth rate and initial height as the dependent variable. The species specific regression models were obtained independently for each species by the linear regression using growth rates and initial heights as dependent and independent variables, respectively.

This residual value of the above mentioned regression was used as dependent variable in the next linear stepwise regression to detect the environmental factors determining height growth rate. Forward and backward stepwise variable selection procedure was applied to detect significant environments by SPSS 12.0J, and each individual juvenile was considered as one sample. Among significantly correlated variables, indirect effects will not appear in the linear model selected by the stepwise procedure. The independent variables in the stepwise regression were (1) conspecific total basal area (DBH > $9 \mathrm{~cm}$ ), (2) conspecific juvenile density (height < $10 \mathrm{~m})$, (3) basal area of all species (DBH $>9 \mathrm{~cm})$, (4) slope inclination, (5) specific catchment area, and (6) Laplacian of ground surface. The first two variables (conspecific basal area and juvenile density) represent the JanzenConnell effect. Basal area of all species represents crowding effect and the status in regeneration cycle, i.e. gap, building and mature. The last three variables (slope inclination, specific catchment area, Laplacian) represent topographic environments that may affect height growth. The specific catchment area is the upslope area per unit width of contour (Wilson and Gallant, 2000), which represents soil humidity, and was $\log$ transformed. Since the study plot was situated on the top of a hill (Mukhtar and Koike, 2006), rain water in surrounding area did not flow into the study site except for a limited marginal area. Larger Laplacian indicates more concave ground relief, and was calculated as second derivative of ground height. Topographic variables were calculated using a free GIS (Koike, 2005) from $1 \mathrm{~m}$ mesh DEM based on a contour map drawn by Ogino et al. (1984). Values of the six independent variables were calculated for each subplot (approximately $100 \mathrm{~m}^{2}$ ).

\section{RESULTS AND DISCUSSION}

In all seven species there were more small sized juveniles than large juveniles, and height distribution was L-shaped (Fig. 1). The average height growth rate of Calophyllum soulattri was significantly smaller than other six species both in saplings and small juvenile trees (Table 1). These six species had approximately equivalent growth rates. Average height growth rate of both saplings and small juvenile trees was less than $2 \mathrm{~cm} /$ year in Calophyllum soulattri, and were 3.6 to $6.4 \mathrm{~cm} /$ year in other species.

Height growth rate negatively correlated to initial height in Calophyllum soulattri (Table 1), however, it correlated positively in Cleistanthus glandulosus, 

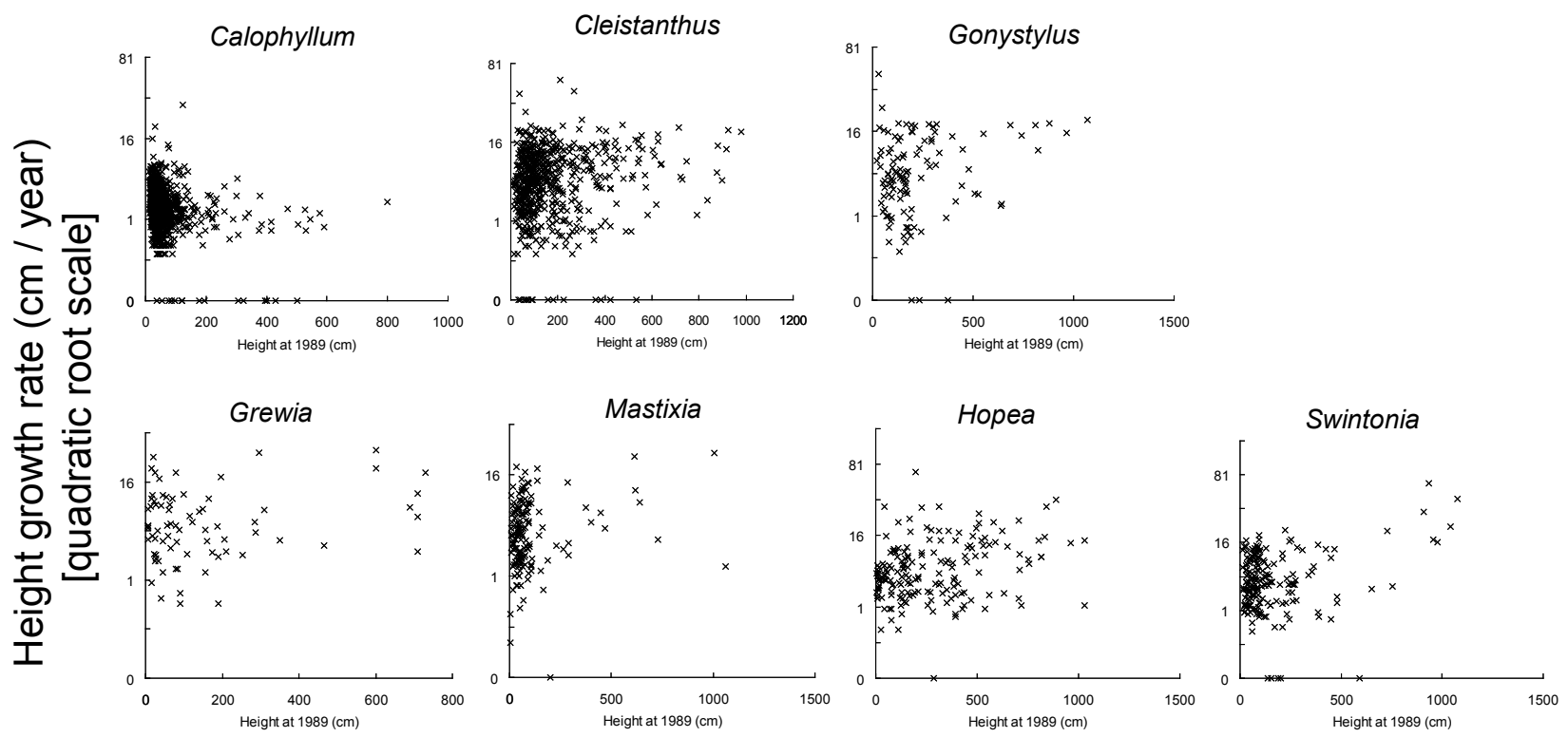

Height $(\mathrm{cm})$

Fig. 1. The relationship between initial height $(\mathrm{cm})$ and height growth $\mathrm{rate}(\mathrm{cm} / \mathrm{year})$ of seven major species. Since height growth rate shows skewed distribution, transformation by quadratic root was applied

Table 1. Height growth rate of seven major species. Correlation coefficient between height at 1989 and quadratic root of growth rate between 1989 and 1998 was calculated for all juveniles (height $<10$ $\mathrm{m})$. Average height growth rate was calculated for saplings (height $<1 \mathrm{~m}$ ) and small juvenile trees $(1 \mathrm{~m}<$ height $<10 \mathrm{~m})$. Only survived individuals during study period were analyzed. Quadratic root of height growth rate was used in all calculations and statistical test to normalize the frequency distribution of growth rate (Fig. 1).

\begin{tabular}{lcccc}
\hline \multicolumn{1}{c}{ Species } & $\begin{array}{c}\text { Number } \\
\text { of } \\
\text { juveniles }\end{array}$ & $\begin{array}{c}\text { Correlation } \\
\text { between height } \\
\text { and growth rate }\end{array}$ & $\begin{array}{c}\text { Average height } \\
\text { growth rate of } \\
\text { saplings } \\
\text { (cm/year) }\end{array}$ & $\begin{array}{c}\text { Average height } \\
\text { growth rate of } \\
\text { small juvenile trees } \\
\text { (cm/year) }\end{array}$ \\
\hline Calophyllum soulattri. & 1170 & $-0.264^{\star}$ & $1.93^{\mathrm{a}}$ & $1.13^{\mathrm{a}}$ \\
Cleistanthus glandulosus & 607 & $0.125^{\star *}$ & $4.21^{\mathrm{b}}$ & $5.47^{\mathrm{b}}$ \\
Gonystylus forbesii & 113 & $0.117^{\star *}$ & $4.43^{\mathrm{b}}$ & $4.66^{\mathrm{b}}$ \\
Grewia florida & 75 & 0.21 & $5.41^{\mathrm{b}}$ & $6.44^{\mathrm{b}}$ \\
Hopea dryobalonoides & 173 & $0.274^{\star *}$ & $3.81^{\mathrm{b}}$ & $5.98^{\mathrm{b}}$ \\
Mastixia trichotoma & 154 & $0.174^{\star}$ & $3.90^{\mathrm{b}}$ & $4.16^{\mathrm{b}}$ \\
Swintonia schwenkii & 191 & $0.276^{\star \star}$ & $4.15^{\mathrm{b}}$ & $3.63^{\mathrm{b}}$ \\
\hline
\end{tabular}

${ }^{\star} \mathrm{P}<0.05,{ }^{*} \mathrm{P}<0.01 ;{ }^{\text {ab }}$ Groups detected by multiple $\mathrm{t}$-test with Bonferroni correction at the level of $\mathrm{P}<0.05$.

Gonystylus forbesii, Hopea dryobalonoides, Mastixia trichotoma and Swintonia schwenkii. Despite its positive correlation, the average growth rate of small juvenile trees $(1 \mathrm{~m}<$ height $<10 \mathrm{~m})$ was smaller than saplings (height $<1 \mathrm{~m}$ ) in Swintonia schwenkii (Table 1). This was because many plants just larger than $1 \mathrm{~m}$ had small growth rate. Significant correlation was not found for Grewia florida.

Forward and backward stepwise regression of the adjusted height growth rate on various factors gave the same result. Negative effect of conspecific plants (juvenile density of the own species) was detected only in Calophyllum soulattri (Table 2). Topography was significant in two species, Hopea dryobalonoides and Mastixia trichotoma. Hopea dryobalonoides grew faster in wet and steep sites, and Mastixia trichotoma in valleys. Swintonia schwenkii grew faster in places with low total basal area. There was no significant correlation between height growth rate and environmental variables for Cleistanthus glandulosus, Gonystylus forbesii and Grewia florida.

Negative effect of conspecific plants on height 
Table 2. Environmental variables significantly affecting height growth rate of juveniles. Height growth rate of individual juveniles between 1989 and 1998 was transformed by quadratic root, and effect of height in 1989 was removed by calculating residuals of linear regression of growth rate and height. Dependent variable was the residual, and independent variables were basal area of all species, conspecific basal area, conspecific juvenile density, slope inclination, log catchment area, and laplacian of each subplot. Laplacian represents concavity of ground relief and was calculated as second derivative of ground height. Environmental variables were selected by stepwise procedure.

\begin{tabular}{|c|c|c|}
\hline Species & $\begin{array}{c}\text { Best linear model selected by stepwise } \\
\text { procedure }\end{array}$ & $\begin{array}{l}\text { Correlation coefficient to individual } \\
\text { environmental variable }\end{array}$ \\
\hline Calophyllum soulattri & $\begin{array}{l}\text { - Conspecific juvenile density ** } \\
\qquad r^{2}=0.035\end{array}$ & $\begin{array}{c}\text { Conspecific juvenile density, } r=-0.187^{* *} \\
\text { Own BA, } r=-0.159^{* *} \\
\text { Catchment area, } r=0.094^{\star *} \\
\text { Laplacian, } r=0.074^{*}\end{array}$ \\
\hline Cleistanthus glandulosus & $\mathrm{ns}$ & ns \\
\hline Gonystylus forbesii & $\mathrm{ns}$ & ns \\
\hline Grewia florida & $\mathrm{ns}$ & $\mathrm{ns}$ \\
\hline \multirow[t]{2}{*}{ Hopea dryobalonoides } & + Catchment area ${ }^{* *}+$ Inclination* & Catchment area, $r=0.212^{\star *}$ \\
\hline & $r^{2}=0.074$ & Inclination, $r=0.171^{*}$ \\
\hline \multirow[t]{2}{*}{ Mastixia trichotoma } & Laplacian** & Laplacian, $r=0.237 * *$ \\
\hline & $r^{2}=0.056$ & Conspecific juvenile density, $r=-0.164^{*}$ \\
\hline \multirow[t]{2}{*}{ Swintonia schwenkii } & - Total BA** & Total BA, $r=-0.209 * *$ \\
\hline & $r^{2}=0.044$ & \\
\hline
\end{tabular}

+ and - stand for positive and negative effects, respectively; ${ }^{* *} \mathrm{P}<0.01$; ${ }^{*} \mathrm{P}<0.05$; ns: not significant.

growth was detected in only one species. Conspecific effects on survivorship was significant in three of studied species in the same forest (Mukhtar and Koike, 2007). Thus, the effect of conspecific plants may work stronger on survival rate than height growth. Species specific herbivory and pathogen are often considered as a cause of negative effects by conspecific neighbors (Janzen, 1970); however, these factors might cause death of the whole plant instead of reduction of growth rate in early growth stage of trees.

Calophyllum soulattri showed different behavior from other major species, and had small growth rate and negative response of growth rate to plant height. Although survivorship of this species was not significantly higher than other species (Mukhtar and Koike, 2007), juveniles of Calophyllum soulattri might have long-lived leaf (Mukhtar, 1985, Unpublished data), and can survive in forest floor without producing new shoots. Species with shorter leaf lifespan should produce new shoots to maintain its foliage-crown, consequently causing height growth, but otherwise they should die.

Effect of environmental factors on survivorship of juveniles in our previous report (Mukhtar and Koike, 2007) showed similar phenomena to height growth presented in this research. Palmiotto et al. (2004) reported that Hopea dryobalanoides had significantly higher growth rate in udult soils, which was wetter and more nutrient rich and Swintonia schwenkii had significantly higher growth rate in humult soils, which was drier and less nutrient in Sarawak. Similar result was also observed by Itoh (2006, personal communication) and Suzuki (2006, personal communication) for Hopea dryobalanoides. Kubota et al. (2000) found richer nutrient status at the lower site of the study plot than the upper site. Such fertility and humidity status could be related to height growth rate of Hopea dryobalanoides and Mastixia trichotoma.

\section{ACKNOWLEDGEMENTS}

We would like to express our appreciation to Prof (Emiretus) Mitsuru Hotta, Prof (Emiretus) Kazuhiko Ogino and Prof Tsuyoshi Yoneda (Kagoshima University) for their initiation and valuable advices for this research. This study is based on a long-term observation, and the late Prof. Syunzo Kawamura of Kyoto University had supported this study throughout the period under the Sumatra Nature Study (SNS) Project and the Field Biology Research and Training (FBRT) Project in Padang. We also give our thanks to Prof. Eizi Suzuki and Prof. Takashi Kohyama for their permission to use their initial data. We are grateful to Prof Marlis Rahman, 
Prof Syahbuddin and students of the Department of Biology, Andalas University, Indonesia, for their advice and help in the field. Thanks are also due to Mr. William L. Ding-Everson, Programme Assistant of CITYNET, The Regional Network of Local Authorities for the Management of Human Settlements, Yokohama, Japan, who kindly corrected the English of this manuscript. The first author (Erizal Mukhtar) would like to thank TPSDP (Technological and Professional Skills Development Sector Project, ADB Loan No. 1792-INO) for financial support for his Visiting Research Fellowship at Yokohama National University, Japan.

\section{REFERENCE}

Beckage, B. \& Clark, J.S. 2003. Seedling survival and growth of three forest tree species : The role of spatial heterogeneity. Ecology 84: 1849-1861.

Beckage, B., Lavine, M. \& Clark, J.S. 2005. Survival of tree seedlings across space and time : estimates from long-term count data. Journal of Ecology 93: 1177-1184.

Bloor, J.G. \& Grubb, P. J. 2003. Growth and mortality in high and low light: trends among 15 shade-tolerant tropical rain forest tree species. Journal of Ecology 91: 77-85.

Hunt, R. 1982. Plant Growth Curves. The Functional Approach to Plant Growth Analysis. University Park Press, Baltimore.

Janzen, D.H. 1970. Herbivores and the number of tree species in tropical forests. The American Naturalist 104: $501-527$.

King, D.A., Davies, S.J., Nur Spardi, M. N. \& Tan, S. 2005. Tree growth is related to light interception and wood density in two mixed dipterocarp forests of Malaysia. Functional Ecology 19: 445-453.

Kohyama, T., Hotta, M., Ogino, K., Syahbuddin \& Mukhtar, E. 1989. Structure and dynamics of forest stands in G. Gadut, West Sumatra. In M. Hotta (Ed) "Diversity and plant animal interaction in equatorial rain forests". Occassional papers of the Kagoshima University Research Center for South Pacific 16: 33-47.

Kohyama, T., Suzuki, E. \& Hotta, M. 1994. Spatial distribution pattern of representative tree species in a foothill rain forest in West Sumatra. Tropics 4: 1-15.

Koike, F. 2005. Minna de GIS. URL:www13.ocn.ne.jp/ $\sim$ minnagis/ (In Japanese)

Koike, F \& Syahbuddin. 1993. Canopy structure of a tropical rain forest and the nature of an unstratified upper layer. Functional Ecology 7: 230-235.

Kubota, D., Masunaga, T., Hermansyah., Hotta, M. \& Wakatsuki, T. 2000. Soil quality characterization in relation to tree species diversity in tropical rain forest, West Sumatra, Indonesia: I. Comparison of two 1-ha plots. Tropics 9: 133-145.

Lusk, C.H. \& Pozo, A.D. 2002. Survival and growth of seedlings of 12 Chilean rainforest trees in two light environments: Gas exchange and biomass distribution correlates. Austral Ecology 27: 193-182.

Massey, F.P., Massey, K., Press, M.C. \& Hartley, S. E. 2006. Neighbourhood composition determines growth, architecture and herbivory in tropical rain forest tree seedlings. Journal of Ecology 94: 646-655.

Mukhtar, E. 1985. Beberapa aspek permudaan pohon di bukit Pinang-pinang. (Several aspects of shoot phenology in Pinang-pinang Hill ). Doctorandus Thesis, Andalas University, Padang (In Indonesian with English summary).

Mukhtar, E., Suzuki, E., Kohyama, T. \& Rahman, M. 1992. Regeneration process of a climax species Calophyllum cf. soulattri in tropical rain forest of West Sumatra. Tropics 2: 1-12

Mukhtar, E: Yoneda, T., Zalfiati \& Rahman, M. 1998. Regeneration process of a climax species Calophyllum cf. soulattri in tropical rain forest of West Sumatra : Population Dynamics of a Cohort from Mast Fruiting in 1981. Tropics 7: 183-194

Mukhtar, E. \& F. Koike. 2007. Dispersal and survival of juveniles of several tree species in a tropical rain forest of West Sumatra. Tropics 16: 205-214

Nathan, R \& Muller-Landau, H. 2000. Spatial patterns of seed dispersal, their determinants and consequences for recruitment. Tree 15: 278-285.

Nathan, R \& Casagrandi, R. 2004. A simple mechanistic model of seed dispersal, predation and plant establishment: Janzen-Connell and beyond. Journal of Ecology 92: 733-746.

Neptali, R.M. 2003. Survival and growth of tree seedlings in anthropogenically disturbed Mexican montane rain forests. Journal of Vegetation Science 14: 881-890.

Ogino, K., Hotta, M., Tamin, R. \& Yoneda, T. 1984. Forest ecology of G. Gadut area. In M. Hotta (Ed) "Forest ecology and flora of G. Gadut West Sumatra". Sumatra Nature Study (Botany), Kyoto, Japan. pp. 15-37.

Palmiotto, P.A., Davies, S.J., Vogt, K.A., Ashton, M.S., Vogt, D.J. \& Ashton, P.A. 2004. Soil-related habitat specialization in dipterocarp rain forest tree species 
in Borneo. Journal of Ecology 92: 609-623.

Pearson, T.R.H, Burslem, D.F.R.P., Goeriz, R.E \& Dalling, J.W. 2003. Interactions of gap size and herbivory on establishment, growth and survival of three species of neotropical pioneer trees. Journal of Ecology 91: 785-796.

Rijkers, T., Pons, T.L. \& Bongers, F. 2000. The effect of tree height and light availability on photosynthetic leaf traits of four neotropical species differing in shade tolerance. Functional Ecology 14: 77-86.

Suzuki, E. \& Kohyama, T. 1991. Spatial distributions of wind-dispersed fruits and trees of Swintonia schwenkii in a tropical forest of West Sumatra. Tropics 1: 131-142.

Uriarte, M., Condit, R., Canham, C.D. \& Hubbell, S. P. 2004. A spatially explicit model of sapling growth in a tropical forest: does the identity of neighbours matter ?. Journal of Ecology 92: 348-360.

Wilson, M \& Traveset, A. 2001. The ecology of seed dispersal. In M. Fenner (ed) "Seeds : The ecology of regeneration in plant communities". 2 nd Edition. $\mathrm{Pp}$ 85-110.

Wilson, J.P. \& Gallant, J.C. 2000. Digital Terrain Analysis. In J.P. Wilson and J.C. Gallant (eds) "Terrain Analysis”. Pp 1-27.

Yoneda, T., Tamin, R \& Ogino, K. 1990. Dynamics of aboveground big woody organs in a foothill dipterocarp forest, West Sumatra, Indonesia. Ecological Research 5: 111-130.

Yoneda, T., Ogino, K., Kohyama, T., Tamin, R., Syahbuddin \& Rahman, M. 1994. Horizontal variance of stand structure and productivity in a tropical foothill rain forest, West Sumatra, Indonesia. Tropics 4: 17-33.

Yoneda, T., Mizunaga, H., Nishimura, S., Fujii, S., Mukhtar, E., Hotta, M \& Ogino, K. 2006. Impacts of recent dry weather on a tropical rain forest in Sumatra with special reference to stand dynamics during the last two decades. Tropics 15: 189-200

Received $22^{\text {nd }}$ June 2006

Accepted $18^{\text {th }}$ Apr. 2008 